\title{
NCR2 wt Allele
}

National Cancer Institute

\section{Source}

National Cancer Institute. NCR2 wt Allele. NCI Thesaurus. Code C104544.

Human NCR2 wild-type allele is located in the vicinity of 6p21.1 and is approximately 15 $\mathrm{kb}$ in length. This allele, which encodes natural cytotoxicity triggering receptor 2 protein plays a role in natural killer cell function. 